\title{
Review of the book The Inkblots by Damion Searls
}

\author{
Recenzja książki autorstwa Damiona Searlsa pt. The Inkblots
}

Anna Hunca-Bednarska

MONAR center in Lublin

\section{Drink in, oh eyes, all your lashed can hold of the golden abundance of the world!} Gottfried Keller

On the back flap of the book The Inkblots by Damion Searls there are the words of Peter Mendelsund saying that the present publication is, in fact, three books in one: an engaging biography of Hermann Rorschach, a vivid and meticulously researched history of the inkblots and a fascinating exploration of the psychology of perception.

The biography of the Swiss psychiatrist is written in an excellent style, what is far from surprising as Searls is a brilliant writer and a translator of many great works of the world literature. From my point of view, it is important that, despite the author's evident emotional involvement, the presentation of the inkblots author is based on voluminous documentation and concerns mostly the development of Rorschach's thought and his desire to explain the relationship between body, mind and the world. It may be concluded that the biographical thread equally displays Searls' literary talent and his impartiality of a researcher.

The nineteenth century saw a great interest in esthetics (how humans receive stimuli and what perception means) as well as kinesthesia (how humans experience movement). We do not know exactly what Rorschach's reading list was. However, we can assume that he was familiar with the ideas of Robert Vischer, knowing at least the works written under the influence of this author. Vischer(1847-1933) studied the way humans perceive abstract forms and the emotions evoked by them. He concluded that what we see in outer shapes is what we had previously 'put' in them. That is, our contact with the world consists in investing in it and then internalizing it.

The attempts to translate the German word Einfühlung (feeling-in) used by Vischer resulted in the invention of the term empathy. Here, however, empathy is neither understood as altruism nor kindness directed towards other people, but as an innovative and original way of describing the relationship between self and the world. Vischer asserted that while looking at a stationary object, he is able to place himself easily within the inner structure of that object, find himself, in a way, at its center of gravity. Visual stimuli are experienced not so much by our eyes, he stated, but in our whole bodies. Owing to this, we are able to make contact with the world, even at the cost of losing a bit of our personalities. Searls remarks that Vischer had traced the same creative activity which Sigmund Freud studied a few decades later. However, while Freud struggled to penetrate the depths of the psyche by the analysis of seemingly chaotic and bizarre surface of dreams, Vischer chose the opposite direction: he followed from the inside of a human being to what we see in the external world (we can say that Freud gave rise to modern psychology, and Vischer was the father of modern art). According to Searls, the motto from Rorschach's favorite poem in German evokes an image of an abundant cup or vessel generously brimming over, representing the richness of the visual world that can be literally 'drunk' with one's eyes. In her book Subjectivity in Motion. Life, Art, and Movement in the Work of Hermann Rorschach(2013), Naamah Akavia, another researcher interested in Rorschach, points out that such words as 'to flow' or 'inflow' frequently appear in Rorschach's texts and this sole fact indicates Rorschach's fascination not only with visual impressions but also with a dynamic interplay between a subject and an object, between the perception of the movement emanating from the external world and the perception of the movement experienced in one's own body.

To my knowledge, both Searls' and Akavia's books have been so far the most important publications concerning Rorschach and his work released recently. They complete each other and are mutually reinforcing. Noteworthy are the similarities in the authors' attitudes which verify mutual conclusions arising after reading their texts.

Firstly, we become aware of the importance of Rorschach's original thought which has often been distorted or simply not taken into consideration sufficiently. It is frequently forgotten that Rorschach never argued that his inkblot cards are a test (here, I use the term 'test' as a useful mental short-cut thus adjusting to a widespread attitude towards this method). Quite on the contrary - Rorschach claimed that the cards are an experiment which should not 
be administered to classify the person to some category, but an experiment that reveals and discovers the person's experience of the world.

Secondly, we can notice, on the one hand, how much the concept of perception and Rorschach's method of its study was supported by the contemporary psychological and philosophical thought as well as by the artistic trends. On the other hand, it becomes clear that the inkblots have always been the focus of interest of philosophers, artists and theorists of art and literature. Although Rorschach's test tends to be associated with psychology and psychiatry, from the beginning it has been rather a cultural phenomenon, which, with time, has been more and more evident. Searls, who had an opportunity to track the history of the inkblots literally up to this day, showed the development of the test, its applications and abuse, and how the test entered the popular culture.

Searls provides examples of how Rorschach interpreted the utterances of the test takers. In his work Psychodiagnostics published in 1921 Rorschach asserted that what matters is not what a patient sees in inkblots, not the content of a patient's utterances but rather the way the inkblots are perceived. In other words, Rorschach emphasised the importance of formal features of the perceptions. However, having started private practice as a therapist, Rorschach noticed that also the content of the utterances, i.e. what the tested person actually sees, is equally significant. According to Searls, Rorschach's interpretations were accurate and never precipitant. The Swiss psychiatrist was consequent in his claim that the explanation of the utterance should always be subordinated to the analysis of its formal features and the relationship between such determinants of the utterance as the shape of the blots, their color and dynamics emanating from inkblots. Additionally, Rorschach focused on how the test takers verbally structure their utterances and paid attention to the utterances describing the very structure of the blot (e.g. I have an impression that there's something powerful in the middle to which everything else clings and it is as though this red thing in the middle were a power to separate the two blocks preventing them from meeting). In John Exner's interpretation system (created from 1950s to approximately 2005) such utterances are categorized as abstract and are included into the so called intellectualization index.

Rorschach also analysed the sequence of utterances. What he found particularly important was the time when the first 'movement' utterance appears. That is to say, the further the card with the movement appears, the stronger the neurotic block of empathy is. Rorschach also attached importance to the order of reactions within particular cards. For instance, whether the tested person starts with popular associations and then proceeds to the original ones, or maybe some other order of reactions is more typical of the given person.

Searls' greatest merit is showing the insight of Rorschach's analyses of the test takers utterances, immensity of his intuition as well as his talent for interpretation. It is worth noting that Rorschach's therapeutic practice was very short, ended by his premature death on 2 April 1922. I am concerned that even those psychologists who are familiar with the test and the specialist literature are inclined to ascribe the above mentioned interpreting methods to Rorschach's followers. In fact, however, it was Rorschach himself who came up with those observations.

The present review cannot address all the issues raised in Searls' book. One can say that the author embraces all the essential problems relating to the development of the Rorschach Test as well as its reception and practical use. Importantly, Searls reports the problems professionally and clearly. The readers who have not had an opportunity to familiarize themselves with the test are provided with a comprehensive look at the nature of the test and the emotions and controversies it evokes. On the other hand, the readers-including experienced psychologists - acquainted with this issue, will also find plenty of new information, not to mention huge inspiration and great amount of pleasure derived from reading.

In his book, Searls shows the immensity of the work done by Exner which resulted in almost complete change into more psychometric character of the test. The author of The Inkblots is aware of light and shadow of such attitude. Personally, I take the view that Exner's book The Rorschach, A Comprehensive System classifies all the information derived from the test. This, in turn, together with labeling the utterances with appropriate signatures, makes it possible to fully use all the gathered material. A set of all the indices allows for statistical analysis and comparison of the results obtained in different groups of subjects. My personal experience in application of the Rorschach Test shows that Exner's methods of calculating numerical results oftentimes fail, especially if they are related to mental disorder. In fact, Exner's methods seem to work mostly with intensified psychopathology. Nevertheless, thanks to such indices, a psychologist is provided with a certain model that orders train of thought and enables him or her to make an adequate diagnosis independently of the score the subject obtained within a particular index. What is more, there is no reason why one cannot look at the utterances from the point of view of dynamic psychology or hermeneutics after gathering quantitative data.

Searls familiarizes the reader with the style of work of Stephen Finn, an American therapist whose thoughts were published in the late 1990s. Doctor Finn let his patients interpret their own utterances, as it frequently 
became clear that one is the best expert when it comes to oneself and one's own problems.

Doctor Finn's clients' ideas became a tangible and simultaneously personal material for further work. Needless to say, such behaviour of the therapist frees the patients from the pressure of authority and gives them a sense of autonomy and empowerment in the psychotherapy process. Searls is strongly convinced that the utterances of a person tested with Rorschach Test reflect his/her authentic experiences since 'You can manage what you want to say, but you can't manage what you want to see'.

Searls' book also provides information about the newest interpretative system of the Rorschach Test by Gregory Meyer, Donald Viglione, Joni Mihura, Philip Erdberg and Robert Erard. The system was published in 2011 as the "Rorschach Performance Assessment System: RPAS". Regrettably, the assessment of this method requires thorough research and as such it is far beyond the scope of this brief review.

The author of The Inkblots does not hesitate to present numerous discussions concerning the test and even deep conflicts between the researchers. Furthermore, he shares his own experiences relating to the inkblot test. The controversial issues that arose over the test, however, must be put aside in this review as they would require a separate comprehensive study.

Searls' work is remarkably well documented; it presents the author's professional knowledge he acquired not only about the history of the test itself but also about the people involved, often known only from brief references in textbooks. Moreover, Searls discusses numerous purely theoretical problems of psychology. For me, a pleasant detail was Searls' gratitude for Rita Signer from the Rorschach Archives and Collection in Bern since special thanks to her were also given by Naamah Akavia in her book.

Alongside the ongoing big wars around the Rorschach Test, the ten boards with the inkblots have remained unmoved and unchanged since 1921. The inkblots cards harmoniously join valuable contradictions: between the obvious and the unobvious, the meaningful and the amorphic, the artistic and what cannot be assessed by the canons of art. Through balancing of these apparent contradictions, the inkblots are a perfect method for the study of the way a human being experiences and responds to the world. Furthermore, the results of such studies facilitate a better insight into one's inner self and, sometimes, help to make a decision to start a therapy.

pod wpływem tego autora. Vischer ( 1847-1933 ) starał się dociec, jak człowiek patrzy na formy abstrakcyjne oraz jakie emocje one w nim budzą i stwierdził, że to, co odczytujemy w zewnętrznych kształtach jest tym, co sami uprzednio w nie „włożyliśmy”; kontakt ze światem polega na inwestowaniu w niego, a następnie na zinternalizowaniu go. Przy próbach przekładu wyrazu niemieckiego Einfühlung (feeling-in), którym posługiwał się Vischer, zaczęto używać terminu empatia. Tutaj jednak empatia to nie altruizm ani nie akt życzliwości skierowany do innych ludzi, ale określenie w nowy, oryginalny sposób relacji między selfem a światem. Vischer pisał, że patrząc na jakiś nieruchomy przedmiot, bez trudu potrafi umieścić siebie samego w wewnętrznej strukturze tego obiektu, znaleźć się jakby w centrum ciężkości tej rzeczy. Wizualne bodźce doświadczane są nie tyle przez nasze oczy, ale w całym naszym ciele; w pewnym sensie tracimy w ten sposób własną tożsamość, ale dzięki temu jesteśmy w stanie nawiązać kontakt ze światem. Searls zauważa, że Vischer śledził tę samą twórczą aktywność, którą starał się zbadać kilka dekad później Zygmunt Freud; ale podczas gdy Freud usiłował przeniknąć do głębi psychiki, analizując pozornie niespójną i dziwaczną powierzchnię marzeń sennych, Vischer podążał w odwrotnym kierunku, przechodził od wnętrza człowieka do tego, co widzi on w świecie zewnętrznym ( możemy powiedzieć, że w ten sposób Freud dał podwaliny współczesnej psychologii, Vischer zaś był ojcem nowoczesnej sztuki ).

Motto wyjęte z ulubionego wiersza Rorschacha, jak pisze Searls, w niemieckim oryginale łączy się z obrazem 
przepełnionego po brzegi, przelewającego się naczynia, oddając w ten sposób bogactwo wizualnego świata, które ma być dosłownie „wypite” przez oczy. Inna badaczka zainteresowana Rorschachem, Naamah Akavia, w swej książce Subjectivity in Motion. Life, Art, and Movement in the Work of Hermann Rorschach z 2013 roku, zwraca uwagę na to, że takie wyrazy jak "płynąć" czy "napływ" często pojawiają się w tekstach Rorschacha i nawet sam ten fakt świadczy już o tym, że był on zafascynowany nie tylko wrażeniami wzrokowymi, ale także i przede wszystkim, dynamiczną współgrą między podmiotem a przedmiotem, między percepcją ruchu emanującego ze świata zewnętrznego i percepcją ruchu odczuwanego we własnym ciele.

Według mojej wiedzy, książka Searlsa i książka Akavii to dwie najpoważniejsze pozycje dotyczące Rorschacha i jego dzieła, jakie ukazały się w ostatnich latach; uzupełniają się one wzajemnie i wspierają. Warto zauważyć podobieństwo postaw obojga autorów, podobieństwa te bowiem weryfikują wzajemnie wnioski, jakie nasuwają się z lektury ich tekstów.

Po pierwsze, uświadamiamy sobie, jak bardzo potrzebny jest powrót do oryginalnej myśli Rorschacha, myśl ta bowiem nierzadko bywała zniekształcana lub po prostu nie brana pod uwagę w dostatecznym stopniu. Najczęściej zapomina się o tym, że Rorschach nigdy nie twierdził, że jego tablice z plamami atramentowymi są testem ( używam tego terminu jako wygodnego skrótu myślowego, a jednocześnie dostosowuję się do powszechnej dziś postawy w stosunku do tej metody badania), ale że są eksperymentem, który nie służy do zaklasyfikowania badanej osoby do jakiejś kategorii, ale który ujawnia, odkrywa, jakie jest jej doświadczanie świata.

Po wtóre, widzimy jak bardzo z jednej strony pojęciu percepcji i metodzie jej badania stworzonym przez Rorschacha sprzyjała współczesna mu myśl psychologiczna, filozoficzna oraz prądy artystyczne, a z drugiej strony jak bardzo plamami atramentowymi zawsze zainteresowani byli filozofowie, artyści, teoretycy literatury i teoretycy sztuki. Chociaż test Rorschacha zwykło łączyć się z psychologią i psychiatrią, od samego początku był on zjawiskiem kulturowym, i ten kulturowy charakter z biegiem czasu staje się coraz bardziej widoczny. Searls, który śledził losy plam atramentowych dosłownie do dnia dzisiejszego, ukazał jak test ten ewaluował, jak go stosowano i jak nadużywano, a także jak wiedza o nim przedostała się do kultury masowej.

Searls daje przykłady, w jaki sposób Rorschach interpretował wypowiedzi badanych. W swoim dziele Psychodiagnostics, wydanym w 1921 roku, stał on na stanowisku, że ważne jest nie to, co badana osoba widzi w plamach, jaka jest treść jej wypowiedzi lecz to, w jaki sposób widzi, czyli istotniejsze są formalne cechy spostrzeżeń. Gdy Rorschach rozpoczął prywatną praktykę jako terapeuta dostrzegł, że ważne jest także to, co widzi badany, jaka jest treść tego, co mówi. Z tego, co pisze Searls wynika, że interpretacje Rorschacha były celne, a nigdy pochopne; szwajcarski psychiatra konsekwentnie twierdził, że wyjaśnianie treści wypowiedzi zawsze powinno być podporządkowane analizie jej cech formalnych, relacjom jakie zachodzą między takimi determinantami wypowiedzi jak kształt plam, ich kolor czy emanująca z plam dynamika. Autor plam atramentowych zwracał też uwagę na to, jak badany konstruuje swoje wypowiedzi w warstwie słownej (dziś powiedzielibyśmy: jaka jest jego werbalizacja ); docenił także wagę wypowiedzi opisujących samą strukturę plamy (np. wypowiedź typu: mam wrażenie, że jest tu coś potężnego w środku, a cała reszta dq̨ży do tego środka lub to jest tak, jakby ta czerwona rzecz $w$ środku miała moc oddzielania dwóch boków, zapobiegając temu, by się spotkały). Takie wypowiedzi w systemie interpretacyjnym Johna Exnera (tworzonym od lat pięćdziesiątych ubiegłego wieku do około 2005 roku) opisane są jako wypowiedzi o treści abstrakcyjnej i włączone do tzw. wskaźnika intelektualizacji. Rorschach analizował też sekwencję wypowiedzi; szczególnie ważne było dla niego, na którą tablicę pojawia się pierwsza wypowiedź „ruchowa”. Im dalsza z kolei tablica, na której spostrzegany jest ruch, tym silniejsze neurotyczne zahamowanie empatii. Nie bez znaczenia według Rorschacha było uporządkowanie reakcji w zakresie poszczególnych tablic. Np. czy badany rozpoczyna od skojarzeń popularnych, a następnie podaje wypowiedzi oryginalne, czy też typowy dla badanej osoby jest jeszcze jakiś inny wzorzec reagowania. Wielką zasługą Searlsa jest ukazanie, jak wnikliwie Rorschach analizował wypowiedzi swoich badanych, jak wielka była jego intuicja i talent interpretatorski. Warto zauważyć, że praktyka terapeutyczna Rorschacha była bardzo krótka, bo przerwana jego przedwczesną śmiercią 2. kwietnia 1922 roku. Obawiam się, że nawet psycholodzy obeznani z testem i fachową literaturą na jego temat, skłonni są przypisywać opisane wyżej sposoby interpretowania wypowiedzi kontynuatorom dzieła Rorschacha, nie zdając sobie sprawy, że to właśnie on sam jest autorem tych cennych spostrzeżeń.

Nie sposób poruszyć wszystkich zagadnień, które są omówione w książce; można powiedzieć, że ogarniają one całość istotnych kwestii związanych z rozwojem testu, jego recepcją i praktycznym użyciem. Co ważne, Searls referuje problemy fachowo, a jednocześnie przystępnie. Czytelnik, który nie spotkał się z testem Rorschacha może uzyskać pełny wgląd w to, czym jest ten test i jakie emocje i kontrowersje budzi. Czytelnik znający tę problematykę, w tym także doświadczony psycholog, znajdzie w książce Searlsa wiele nowych informacji, nie mówiąc już o wielkiej inspiracji i przyjemności z lektury.

Searls pokazuje, jak ogromną pracę wykonał Exner; rezultatem tej pracy jest niemalże całkowite nadanie testowi Rorschacha psychometrycznego charakteru. Autor The Inkblots zauważablaski i cienie takiej postawy. Osobiście stoję na stanowisku, że The Comprehensive System Exnera pozwala na uporządkowanie wielości informacji, jakie uzyskujemy $\mathrm{z}$ badania. Uporządkowanie to i nadanie różnym cechom 
wypowiedzi odpowiednich sygnatur sprawia, że bardzo niewiele z zebranego materiału pozostaje niezauważone. Sporządzenie zestawu wszystkich indeksów i wskaźników umożliwia poddanie tak ukształtowanego materiału analizie statystycznej i porównanie wyników uzyskanych w różnych grupach badanych. Moje doświadczenie w stosowaniu testu Rorschacha mówi, że opracowane przez Exnera sposoby obliczania wyników liczbowych nierzadko zawodzą, zwłaszcza gdy dotyczą zaburzeń psychicznych ( najczęściej okazują się diagnostyczne tylko w odniesieniu do bardzo nasilonej psychopatologii). Mimo to posługiwanie się takimi wskaźnikami dostarcza psychologowi pewien wzorzec, porządkuje tok jego rozumowania i pozwala na postawienie trafnej diagnozy, niezależnie od liczby punktów uzyskanych przez badaną osobę w tym czy innym wskaźniku. Co więcej, nic nie stoi na przeszkodzie temu, by po sporządzeniu ilościowych zestawień, nie popatrzeć na wypowiedzi badanego z punktu widzenia psychologii dynamicznej, czy też z punktu widzenia hermeneutyki.

Searls zaznajamia czytelnika ze stylem pracy amerykańskiego terapeuty, doktora Stephena Finna, publikującego swoje przemyślenia w późnych latach dziewięćdziesiątych ubiegłego wieku. Finn pozwalał swoim klientom samodzielnie interpretować własne wypowiedzi - najczęściej okazywało się, że ludzie bywają najlepszymi ekspertami w zakresie samego siebie i swoich problemów. Spostrzeżenia klientów Finna często stawały się „namacalnym,” a jednocześnie „ich własnym” materiałem do dalszej pracy. Myślę, że nie muszę tu zaznaczać, że takie postępowanie terapeuty uwalnia jego podopiecznego od presji autorytetu, daje mu poczucie niezależności i sprawczości w procesie psychoterapeutycznym. Searls jest przekonany o tym, że wypowiedzi osoby badanej testem Rorschacha oddają jej prawdziwe doświadczenia, ponieważ "You can manage what you want to say, but you can't manage what you want to see".

Z książki Searlsa dowiadujemy się o najnowszym systemie interpretowania wyników testu Rorschacha, którego autorami są Gregory Meyer, Donald Viglione, Joni Mihura, Philip Erdberg oraz Robert Erard. Autorzy ci opublikowali swój system w 2011 roku pod nazwą Rorschach Performance Assessment System: R- PAS. Trudno mi ustosunkować się do tych nowych spojrzeń na test, ponieważ ocena taka wymagałaby gruntownych studiów, co przekraczałoby ramy tej niedługiej recenzji.
Autor The Inkblots nie unika przedstawiania dyskusji, jakie toczyły się na temat testu, a nawet głębokich konfliktów między badaczami; dzieli się też z czytelnikiem swymi osobistymi doświadczeniami z testem plam atramentowych. Wątek poświęcony kontrowersjom narosłym wokół testu pozostawiam $\mathrm{w}$ tej recenzji na boku, potrzebne byłoby tu bowiem obszerne, osobne opracowanie tej kwestii.

Książka Searlsa jest niezwykle bogato i skrupulatnie udokumentowana, a jej autor posiadł fachową wiedzę nie tylko o historii testu i ludziach z nim związanych (często znanych jedynie z krótkich wzmianek w podręcznikach), ale także o wielu czysto teoretycznych problemach psychologii. Miłym szczegółem było dla mnie zauważenie, że Searls między innymi dziękuje Ricie Signer z Archiwum Rorschacha w Bernie, bowiem gorące podziękowania za jej pomoc i życzliwość zamieściła też w swojej książce Naamah Akavia.

Obok „wielkich wojen”, jakie przetaczają się wokół testu Rorschacha, niewzruszonym faktem pozostaje istnienie dziesięciu tablic z plamami atramentowymi, tymi samymi od 1921 roku; plamami, które w idealnej harmonii łączą cenne sprzeczności: między oczywistym a nieoczywistym, między znaczącym a amorficznym, w końcu między artystycznym a tym, co nie poddaje się plastycznym kanonom. Dzięki zrównoważeniu tych pozornych sprzeczności, plamy atramentowe stanowią doskonałą metodę do badania tego, jak człowiek doświadcza świata i jak się do niego ustosunkowuje, a wyniki takiego badania umożliwiają lepszy wgląd we własne wnętrze, a czasem podjęcie terapii.

\section{Conflict of interest}

The authors have declared no conflict of interest.

\section{Correspondence address:}

Anna Hunca- Bednarska

Ośrodek MONAR w Lublinie

20-214 Lublin, ul. Montażowa 16

Otrzymano: 12.10 .2017

Zrecenzowano:21.11.2017

Przyjęto do druku: 12.04.2018 